\title{
Bevacizumab in Colorectal Cancer: Current Role in Treatment and the Potential of Biosimilars
}

\author{
Lee S. Rosen ${ }^{1}$ - Ira A. Jacobs ${ }^{2}$ • Ronald L. Burkes ${ }^{3}$ \\ Published online: 11 August 2017 \\ (C) The Author(s) 2017. This article is an open access publication
}

\begin{abstract}
Colorectal cancer (CRC) is a leading cause of tumor-related morbidity and mortality worldwide, with mortality most often attributable to metastatic disease. Bevacizumab, a humanized monoclonal antibody targeting vascular endothelial growth factor, has a significant role in the treatment of metastatic CRC (mCRC). However, patient access to bevacizumab may be limited in some regions or circumstances, owing to factors related to insurance coverage, reimbursement, patient out-of-pocket costs, or availability. As a result, outcomes for patients with mCRC may be worsened. Additionally, counterfeit bevacizumab has infiltrated legitimate supply chains, exposing patients to risk. Oncologists may also be affected detrimentally, since resolving access issues can be time-consuming and demoralizing. The imminent expiry of patents protecting bevacizumab provides other manufacturers with the opportunity to produce highly similar versions known as biosimilars. High-quality, safe, and effective biosimilars have the potential to expand access to bevacizumab. Most of the bevacizumab biosimilars currently in development are in clinical trials in patients with non-smallcell lung cancer, and future authorization for $\mathrm{mCRC}$ indications will, therefore, be based on extrapolation. This article reviews the current role of bevacizumab in the management of $\mathrm{mCRC}$, the possible barriers associated with diminished access to bevacizumab, and the potential bevacizumab
\end{abstract}

Ira A. Jacobs

ira.jacobs@pfizer.com

1 UCLA Division of Hematology-Oncology, 2020 Santa Monica Boulevard, Suite 600, Santa Monica, CA 90404, USA

2 Pfizer Inc, 235 East 42nd Street, New York, NY 10017-5755, USA

3 Mount Sinai Hospital, Joseph and Wolf Lebovic Health Complex, 600 University Avenue, Toronto, ON M5G 1X5, Canada biosimilars in development. How biosimilars may impact the treatment of mCRC is also discussed.

\section{Key Points}

Bevacizumab has demonstrated improved overall survival for patients with metastatic colorectal cancer (mCRC). However, access to this treatment may be limited.

Several potential bevacizumab biosimilars are in late-stage clinical development. These biosimilars have the potential to enhance patient access to bevacizumab.

Few of the potential bevacizumab biosimilars are being studied in patients with mCRC during initial clinical development programs. Therefore, oncologists will need to acquaint themselves with the scientific principles that underlie the regulation of biosimilars, including extrapolation of indications.

\section{Introduction}

Colorectal cancer (CRC) is the second most common cancer in women and the third most common in men [1]. Nearly 1.4 million new cases were identified globally in 2012, as well as nearly 700,000 deaths [1]. CRC accounts for $8.5 \%$ of all tumor-related mortality, and it is the fourth most common cause of cancer death [1]. Incidence is correlated with advancing age and, in developed countries, the median age at diagnosis is approximately 70 years [2]. If diagnosed at an early stage, CRC is associated with a good prognosis [3]. However, $20-25 \%$ of patients present with metastases, and 
approximately half of patients with CRC will eventually develop metastatic disease [3, 4]. Unfortunately, the prognosis is poor for patients presenting with metastatic CRC (mCRC); in the United States (US), for example, the current 5-year survival rate is $13.5 \%$ [3]. As a result, metastatic disease accounts for the high mortality rates associated with CRC.

Management of mCRC has evolved significantly in the past 20 years, however, and survival rates have improved during this time. Indeed, the median overall survival (OS) of patients with $\mathrm{mCRC}$ in clinical trials is now approximately 30 months, double that of two decades ago [5]. Although several factors have contributed to improved clinical outcomes, a key development has been the introduction of novel biologic therapies targeting either epidermal growth factor signaling or angiogenesis [6]. Bevacizumab, a monoclonal antibody directed against vascular endothelial growth factor (VEGF), is among these therapies. By inhibiting the action of VEGF, bevacizumab is thought to cause regression of existing tumor vasculature and prevent the development of new blood vessels, thereby inhibiting tumor growth [7]. Bevacizumab is licensed for the treatment of an array of tumors, including mCRC, non-squamous non-small-cell lung cancer (NSCLC), metastatic renal cell carcinoma, glioblastoma, cervical cancer, and recurrent epithelial ovarian, fallopian tube, or primary peritoneal cancer $[7,8]$.

Although targeted antineoplastic biologics such as bevacizumab are associated with significant clinical benefits, access to these treatments can be limited [9-12]. Biosimilars, which are highly similar versions of licensed biologics, have the potential to provide efficiencies for healthcare systems and increase patient access to these agents. This article reviews the current role of bevacizumab in $\mathrm{mCRC}$, the factors that may limit access to bevacizumab in this patient population, and how the availability of high-quality bevacizumab biosimilars may impact the future clinical management of this challenging condition.

\section{Impact and Current Role of Bevacizumab in $\mathrm{mCRC}$}

In both first- and second-line settings, randomized trials have demonstrated improvements in OS in patients with mCRC treated with bevacizumab in combination with cytotoxic chemotherapy [13-15] (Table 1). In the pivotal AVF2107g study, for example, patients with previously untreated $\mathrm{mCRC}$ who were randomized to receive bevacizumab in combination with irinotecan, bolus fluorouracil, and leucovorin had a median survival of 20.3 months, compared with 15.6 months in patients who received placebo rather than bevacizumab [13]. Benefits in progression-free survival (PFS) and response rate were also noted. Additionally, in a randomized, placebo- controlled trial, improvement in PFS, but not OS or response rate, was observed with bevacizumab in combination with oxaliplatin-based chemotherapy as first-line treatment [21]. Furthermore, in a placebo-controlled trial, bevacizumab was associated with improved PFS when combined with fluorouracil and leucovorin in patients with $\mathrm{mCRC}$ for whom firstline irinotecan was deemed unsuitable, owing to factors such as poor performance status [19]. Findings such as these led bevacizumab to become part of standard first-line treatment for $\mathrm{mCRC}$, in combination with various chemotherapy backbones [5].

In the bevacizumab-naïve, second-line setting, improvements in OS, PFS, and response rate were seen when bevacizumab was combined with FOLFOX (folinic acid, fluorouracil, and oxaliplatin), compared with treatment with FOLFOX alone, in patients with $\mathrm{mCRC}$ previously treated with a fluoropyrimidine and irinotecan [14]. More recently, randomized trials have helped answer the question of whether bevacizumab treatment should be continued following disease progression [15, 26]. In the ML18147 study, patients whose disease progressed on first-line treatment with bevacizumab combined with fluoropyrimidine-based chemotherapy were randomized to receive second-line chemotherapy with or without bevacizumab [15]. Median OS was significantly longer in the bevacizumab group than in the group receiving chemotherapy alone (11.2 vs. 9.8 months, respectively). The similarly designed BEBYP trial, which examined the effect of bevacizumab reintroduction or continuation after progression, was stopped prematurely in light of the results of ML18147 [26]. However, reintroducing or continuing bevacizumab was associated with a statistically significant benefit in the primary endpoint of PFS compared with chemotherapy alone (6.8 vs. 5.0 months, respectively).

Severe toxicity with bevacizumab appears to be uncommon, and most adverse events are clinically manageable [13]. Placebo-controlled trials of bevacizumab have identified higher rates of hypertension, bleeding, venous and arterial thromboembolic events, proteinuria, wound healing complications, and gastrointestinal perforation, among others [27]. Such adverse events might discourage clinicians from using bevacizumab in older patients. However, observational studies, pooled and subgroup analyses from clinical trials, and a recent randomized trial [16] suggest that the safety and efficacy profile of bevacizumab in elderly patients with mCRC does not differ significantly from that in younger patients [28]. Thus, age alone should not be a deciding factor in the use of bevacizumab, notwithstanding the need to carefully consider clinically relevant comorbidities and risk factors [28].

Recent research has focused on further defining the role of bevacizumab in terms of optimal sequencing or combination with cytotoxic and other targeted agents. Other contemporary 
Table 1 Selected randomized controlled studies of bevacizumab in combination with chemotherapy in the treatment of metastatic colorectal cancer

\begin{tabular}{|c|c|c|c|c|c|}
\hline Study & Treatment line & $\begin{array}{l}\mathrm{N} \\
\text { randomized }\end{array}$ & Arms & $\begin{array}{l}\text { Primary } \\
\text { endpoint }(s)\end{array}$ & $\begin{array}{l}\text { HR for primary endpoint } \\
\text { (95\% CI; P-value) }\end{array}$ \\
\hline $\begin{array}{l}\text { Bennouna } \\
\text { et al. [15] }\end{array}$ & $\begin{array}{l}\text { Second (BEV continued } \\
\text { after first progression) }\end{array}$ & 820 & $\begin{array}{l}\text { Oxaliplatin/irinotecan-based chemotherapy + BEV } \\
(5 \mathrm{mg} / \mathrm{kg} \text { Q2W or } 7.5 \mathrm{mg} / \mathrm{kg} \mathrm{Q} 3 \mathrm{~W}) \\
\text { Oxaliplatin/irinotecan-based chemotherapy }\end{array}$ & OS & $\begin{array}{l}0.81(0.69-0.94 \\
\quad P=0.0062)\end{array}$ \\
\hline $\begin{array}{l}\text { Cunningham } \\
\text { et al. [16] }\end{array}$ & First & 280 & $\begin{array}{l}\text { Capecitabine + BEV }(7.5 \mathrm{mg} / \mathrm{kg} \mathrm{Q} 3 \mathrm{~W}) \\
\text { Capecitabine }\end{array}$ & PFS & $\begin{array}{l}0.53(0.41-0.69 \\
\quad \mathrm{P}<0.0001)\end{array}$ \\
\hline $\begin{array}{l}\text { Giantonio } \\
\text { et al. [14] }\end{array}$ & Second & 829 & $\begin{array}{l}\text { FOLFOX4 + BEV (10 mg/kg Q2W) } \\
\text { FOLFOX4 } \\
\text { BEV }(10 \mathrm{mg} / \mathrm{kg} \mathrm{Q} 2 \mathrm{~W})\end{array}$ & OS & $0.75^{\mathrm{a}}(\mathrm{P}=0.0011)$ \\
\hline $\begin{array}{l}\text { Guan et al. } \\
\text { [17] }\end{array}$ & First & 214 & $\begin{array}{l}\mathrm{IFL}+\mathrm{BEV}(5 \mathrm{mg} / \mathrm{kg} \mathrm{Q} 2 \mathrm{~W}) \\
\mathrm{IFL}\end{array}$ & $\begin{array}{l}\text { PFS, } \\
\text { 6-month } \\
\text { PFS }\end{array}$ & $\begin{array}{l}0.44(0.31-0.63 \\
\quad \mathrm{P}<0.001)(\mathrm{PFS})\end{array}$ \\
\hline $\begin{array}{l}\text { Hurwitz et al. } \\
\text { [13] }\end{array}$ & First & 813 & $\begin{array}{l}\mathrm{IFL}+\mathrm{BEV}(5 \mathrm{mg} / \mathrm{kg} \mathrm{Q} 2 \mathrm{~W}) \\
\mathrm{IFL}+\text { placebo }\end{array}$ & OS & $0.66(\mathrm{P}<0.001)$ \\
\hline $\begin{array}{l}\text { Kabbinavar } \\
\text { et al. [19] }\end{array}$ & First & 209 & $\begin{array}{l}\mathrm{FU}+\mathrm{LV}+\mathrm{BEV}(5 \mathrm{mg} / \mathrm{kg} \mathrm{Q} 2 \mathrm{~W}) \\
\mathrm{FU}+\mathrm{LV}+\text { placebo }\end{array}$ & OS & $\begin{array}{l}0.79(0.56-1.10 \\
\quad P=0.16)\end{array}$ \\
\hline $\begin{array}{l}\text { Kabbinavar } \\
\text { et al. [18] }\end{array}$ & First & 104 & $\begin{array}{l}\mathrm{FU}+\mathrm{LV}+\mathrm{BEV}(5 \mathrm{mg} / \mathrm{kg} \mathrm{Q} 2 \mathrm{~W}) \\
\mathrm{FU}+\mathrm{LV}+\mathrm{BEV}(10 \mathrm{mg} / \mathrm{kg} \mathrm{Q} 2 \mathrm{~W}) \\
\mathrm{FU}+\mathrm{LV}\end{array}$ & $\begin{array}{l}\text { TTP, } \\
\quad \text { response } \\
\text { rate }\end{array}$ & $0.54^{\mathrm{b}}(\mathrm{P}=0.013)(\mathrm{TTP})$ \\
\hline $\begin{array}{l}\text { Passardi et al. } \\
\quad[20]\end{array}$ & First & 376 & $\begin{array}{l}\text { FOLFIRI/FOLFOX } 4 \text { + BEV (5 mg/kg Q2W) } \\
\text { FOLFIRI/FOLFOX4 }\end{array}$ & PFS & $\begin{array}{l}0.86(0.70-1.07 \\
\quad P=0.182)\end{array}$ \\
\hline $\begin{array}{l}\text { Saltz et al. } \\
\quad[21]\end{array}$ & First & 1401 & $\begin{array}{l}\text { XELOX/FOLFOX4 + BEV (7.5 mg/kg Q3W or } \\
5 \mathrm{mg} / \mathrm{kg} \mathrm{Q} 2 \mathrm{~W}) \\
\text { XELOX/FOLFOX4 + placebo }\end{array}$ & PFS & $0.83(\mathrm{P}=0.0023)$ \\
\hline $\begin{array}{l}\text { Stathopoulos } \\
\text { et al. [22] }\end{array}$ & First & 222 & $\begin{array}{l}\mathrm{IFL}+\mathrm{BEV}(7.5 \mathrm{mg} / \mathrm{kg} \mathrm{Q} 3 \mathrm{~W}) \\
\mathrm{IFL}+\mathrm{BEV}\end{array}$ & OS & $\mathrm{NR}(\mathrm{P}=\mathrm{ns})$ \\
\hline $\begin{array}{l}\text { Tebbutt et al. } \\
\text { [23] }\end{array}$ & First & 471 & $\begin{array}{l}\text { Capecitabine + mytomycin + BEV }(7.5 \mathrm{mg} / \mathrm{kg} \\
\text { Q3W) } \\
\text { Capecitabine + BEV }(7.5 \mathrm{mg} / \mathrm{kg} \mathrm{Q} 3 \mathrm{~W}) \\
\text { Capecitabine }\end{array}$ & PFS & $\begin{array}{l}0.63^{\mathrm{c}}(0.50-0.79 \\
\mathrm{P}<0.001) \\
0.59^{\mathrm{d}}(0.47-0.75 \\
\mathrm{P}<0.001)\end{array}$ \\
\hline
\end{tabular}

Studies included are those identified in the systematic literature reviews by Botrel et al. [24] and Qu et al. [25]

$B E V$ bevacizumab, $C I$ confidence interval, FOLFIRI folinic acid, fluorouracil, irinotecan, FOLFOX folinic acid, fluorouracil, oxaliplatin, $F U$ fluorouracil, $H R$ hazard ratio, $I F L$ irinotecan, fluorouracil, leucovorin, $L V$ leucovorin, $N R$ not reported; ns, not significant, $O S$ overall survival, $P F S$ progression-free survival, $Q 2 W$ every 2 weeks, $Q 3 W$ every 3 weeks, $T T P$ time to progression, $X E L O X$ capecitabine, oxaliplatin

${ }^{\mathrm{a}}$ For FOLFOX4 + BEV vs FOLFOX4

${ }^{\mathrm{b}}$ For pooled $\mathrm{BEV}$ arms vs $\mathrm{FU}+\mathrm{LV}$

${ }^{\mathrm{c}}$ For capecitabine $+\mathrm{BEV}$ vs capecitabine

${ }^{\mathrm{d}}$ For capecitabine + mytomycin + BEV vs capecitabine

studies have explored the somewhat controversial area of maintenance treatment following first-line induction therapy, with data suggesting that bevacizumab may have a role in this setting [29]. Another current focus is identification of predictive biomarkers for sensitivity and resistance to bevacizumab $[6,27]$, information that would be particularly helpful in the current era of personalized medicine for patients with CRC.

In short, bevacizumab has an important and evolving role in improving outcomes for patients with mCRC. At a population level, evidence in support of its impact comes from an analysis of Canadian patients diagnosed with mCRC in 2003/ 2004 (the "pre-bevacizumab era") or 2006 (the "bevacizumab era") [30]. Median OS was 3.5 months longer in the later cohort, which investigators attributed to an increased proportion of patients receiving systemic therapy and the addition of bevacizumab to chemotherapy. Importantly, no difference in survival was seen when considering patients who did not receive systemic therapy, suggesting that changes in supportive care are unlikely to have contributed to the overall findings. The principal difference between the cohorts in terms of systemic therapy was the use of bevacizumab, which had increased from $5.9 \%$ to $30.6 \%$. Data from the South Australian mCRC registry revealed a similar improvement in OS after bevacizumab was listed on the governmentsubsidized medication scheme in 2009, enabling wider utilization [31]. Although these observational, population-based analyses have methodological limitations, the findings are consistent with the recognition that bevacizumab has contributed to the meaningful improvements in survival observed in patients with $\mathrm{mCRC}$ in recent years. 


\section{Limited Access to Bevacizumab: Barriers and Consequences}

Despite the benefits of bevacizumab in mCRC, access to treatment can be problematic. For example, when Canadian oncologists treating mCRC were surveyed in 2007, at which time bevacizumab was publicly funded in two provinces, fewer than $20 \%$ of respondents reported being able to use the drug regularly in first-line treatment, despite considering it a component of the "ideal" regimen [32]. A 2011 survey of US hospitals that dispensed outpatient chemotherapy found treatment with bevacizumab was restricted in approximately $70 \%$ of institutions [33]. More recently, a 2014-2015 study by the European Society for Medical Oncology found that, although bevacizumab was widely available on formularies for the treatment of CRC at no out-of-pocket cost to patients in Western Europe, the drug was accessible only at full cost in a number of countries in Eastern Europe [9]. Finally, although a majority of the oncologists surveyed in a study published in 2017 reported "always" or "frequently" prescribing bevacizumab for first-line treatment of mCRC, access-related issues were cited as a concern among those physicians not prescribing the drug frequently, particularly in emerging markets (Brazil, Mexico, and Turkey) [12].

The specific barriers to accessing bevacizumab appear to vary according to the country, healthcare system, and clinical scenario concerned [12]. First, access may be limited due to affordability in areas where out-of-pocket expense to patients is relevant. For example, despite acknowledging that cancer patients should have access to effective treatment regardless of cost, oncologists in the US have reported that their treatment recommendations are influenced by patient out-of-pocket expenses [34]. Indeed, of a small sample of US oncologists who reported difficulty accessing bevacizumab for the treatment of mCRC, $40 \%$ highlighted high out-of-pocket expense to patients as an underlying barrier [12].

In regions where healthcare is insurance-based, access to bevacizumab may be limited by plan coverage. In a recent analysis of cancer drug coverage by the American Cancer Society Cancer Action Network, for example, bevacizumab was covered in only $35 \%$ of plan formularies [35]. Among the formularies on which bevacizumab was included, coverage was in the highest cost-sharing tier in 52\% of cases [35]. In countries where health services are publicly funded, such as the United Kingdom, access may be problematic if the drug is not reimbursed. A Cancer Drug Fund was created in England to enhance the accessibility of treatments not available for routine use within the National Health Service [36]; however, funding for bevacizumab in the treatment of $\mathrm{mCRC}$ was discontinued in 2015 [37]. Issues with reimbursement by private insurance or the healthcare system may also impact treatment strategies. In the aforementioned physician survey published in 2017, reimbursement difficulties were cited as the predominant reason for reducing the number of planned bevacizumab treatment cycles for patients with mCRC among oncologists from the US, Europe, and emerging markets [12].

Treatment protocols or guidelines not recommending bevacizumab represent an access barrier in some areas [12]. In guidance from the National Institute for Health and Care Excellence in England and Wales, for example, bevacizumab in combination with oxaliplatin and either fluorouracil plus folinic acid or capecitabine is not recommended for the treatment of $\mathrm{mCRC}$, because it is not considered cost-effective [38, 39]. In another example, investigators in the US have reported hospital-level management or restriction of oncology drugs, including bevacizumab, via mechanisms such as product formularies, treatment-decision teams, and tumor-specific prescribing protocols [33].

Another factor contributing to limited access to bevacizumab is supply availability. In recent years, oncology drugs have been subject to supply problems, caused by manufacturing delays, limited availability of ingredients, and compliance issues [40]. Recent data suggest that bevacizumab is not always available to patients with $\mathrm{mCRC}$ who hold a valid prescription in Finland, Greece, Sweden, and the United Kingdom, as well as various Eastern European countries [9]. In another study, bevacizumab not being available in practice was reported by a small base of oncologists in the US, Europe, and emerging markets; across tumor types, this was a particular issue for clinicians in emerging markets as compared with physicians in other regions [12]. Other authors have predicted that treatment delays and increased costs could result from recent changes to the distribution of bevacizumab, rituximab, and trastuzumab, whereby the supply chain has been limited to six specialty drug distributors rather than drug wholesalers [41].

Finally, certain patient characteristics may be associated with reduced usage of bevacizumab in the context of mCRC. Insurance claims data concerning older patients based in the US reveal that, after controlling for sociodemographic and clinical factors, the likelihood of receiving a biologic is negatively affected by factors such as advancing age, comorbidities, and lower income [42]. Disparities in access are also evident among racial groups [42].

In terms of impact, limited access to bevacizumab prevents patients with mCRC from receiving optimal care, potentially leading to worse clinical outcomes [12]. Oncologists may also be negatively affected; significant time spent resolving access issues can reduce morale and limit their ability to see new patients [32]. A particularly concerning consequence of the need for cost containment is that it has created the opportunity for counterfeit bevacizumab to infiltrate legitimate supply chains, exposing patients to risk as well as denying them the potential benefits of treatment $[43,44]$. Online pharmacies, to which patients may turn in the hope of obtaining affordable treatment, have also been linked with the supply of counterfeit bevacizumab [43]. 


\section{Biosimilars: Concept and Regulation}

In recent years, the expiry of patents protecting a number of biologics has provided the opportunity for other manufacturers to develop biosimilar versions of these therapies. A biosimilar is a biologic that is deemed to be highly similar to a licensed originator product, with no clinically meaningful differences in safety, purity, or potency, following a rigorous comparison exercise [45]. Because biologics are typically large, complex molecules, their structure is highly dependent on the manufacturing process, and even small changes can have significant implications for safety and efficacy. Manufacturers of biosimilars are required to develop their own production processes, meaning that biosimilars, although highly similar to the corresponding originator products, cannot be considered truly "identical." This explains why biosimilars are not generic drugs and is the key reason why biosimilars are approved via a separate, abbreviated regulatory pathway.

In oncology, biosimilars of filgrastim and epoetin have been available in some countries for several years. In Europe, for example, filgrastim biosimilars were first authorized in 2008, and recent data suggest they account for $85 \%$ of filgrastim use and that biosimilar competition has led to price reductions and increased patient access [46]. Across 22 European countries, compared with the year prior to the introduction of biosimilar filgrastim, the average price per treatment-day was $32 \%$ lower in 2015 , and the volume of filgrastim use had nearly doubled. Importantly, no unexpected safety issues have been reported in association with the use of filgrastim biosimilars [47, 48]. Filgrastim and epoetin are relatively small proteins, and developing biosimilars of larger, more-complex therapies, such as monoclonal antibodies, is significantly more challenging for manufacturers. However, recent years have seen the regulatory approval of biosimilars referencing the anti-tumor necrosis factor alpha inhibitors adalimumab, etanercept, and infliximab for the treatment of certain immune-mediated inflammatory conditions. Moreover, in early 2017, the European Medicines Agency authorized biosimilar rituximab CT-P10, the first monoclonal antibody biosimilar to be approved in Europe for the treatment of cancer [49].

The regulatory requirements for demonstrating biosimilarity to an originator product are generally similar in areas such as Canada, Europe, and the US [45, 50, 51]. In each case, the aim is to demonstrate a high degree of similarity to the originator through a stepwise comparison process, rather than to establish de novo safety and efficacy, which have already been demonstrated for the originator product. The process is founded on a robust characterization of physicochemical attributes and biological function, which is typically followed by a nonclinical toxicity assessment and final, confirmatory, clinical comparisons. The scope of the clinical data needed will depend on the extent of residual uncertainty about biosimilarity from previous steps, but an assessment of pharmacokinetics (PK), pharmacodynamics (if relevant), and immunogenicity will be required, and at least one comparative clinical study is usually conducted to establish biosimilarity in safety and efficacy [45, 50-52].

Many originator biologics have multiple indications. As a result, most biosimilar regulatory frameworks permit the concept of extrapolating clinical data from the originator to the biosimilar in those indications held by the originator that are not assessed during the initial comparison exercise [53]. In this way, extrapolation is a core aspect of the biosimilar concept and enables avoiding duplicative clinical trials. As described below, key considerations include the mechanism of action of the active substance in each indication, the target receptors involved, and any differences in the safety or immunogenicity profiles of the product between indications [53]. Although some societies have expressed concerns about extrapolation, others argue that it is a "logical consequence of the biosimilar concept" that has been employed successfully to date [53].

\section{Potential Biosimilars to Bevacizumab: Considerations and Challenges}

Patents protecting bevacizumab in the US and Europe are expected to expire in the next several years [54]. Potential biosimilars to bevacizumab are in development, and at the time of writing, licensing applications for one of the proposed bevacizumab biosimilars (ABP 215) have been submitted to the US Food and Drug Administration and the European Medicines Agency [55, 56]. As outlined above, successful authorization of a bevacizumab biosimilar will be dependent on demonstrating a high degree of similarity to originator bevacizumab in a stepwise comparison exercise encompassing analytical, nonclinical, and clinical studies.

The proposed mechanism of action for bevacizumab is binding to soluble VEGF via the Fab region of the antibody, thereby preventing the interaction of VEGF with endothelial cell-surface receptors VEGFR-1 and -2 by steric blocking and interrupting downstream signaling $[57,58]$. In terms of Fcrelated function, although originator bevacizumab is able to bind human $\mathrm{Fc} \gamma$ receptors and complement protein $\mathrm{C} 1 \mathrm{q}$, it has been shown to lack antibody-dependent cell-mediated cytotoxicity (ADCC) and complement-dependent cytotoxicity (CDC) activities [57].

When characterizing the mechanism of action of a potential bevacizumab biosimilar, data from the foundational comparative analytical assessments are crucial. Results from such studies are available for the potential bevacizumab biosimilars 
ABP 215 and PF-06439535 (e.g. [59, 60]). Considering the structural characterization of PF-06439535 as an example, the potential biosimilar was shown to have an identical amino acid sequence and similar post-translational modifications and biochemical properties to originator bevacizumab, using a range of state-of-the-art techniques [60]. In the functional assessment of ABP 215, the potential biosimilar was found to be similar to originator bevacizumab with respect to VEGF binding and the inhibition of cell proliferation and VEGFR2 autophosphorylation in human umbilical vein epithelial cells [59]. Similarity in terms of the Fc region was also demonstrated in terms of in vitro binding to FcRn and FcR $\gamma$ IIIIa. Moreover, a lack of ADCC and CDC functionality was confirmed during the comparison [59]. As part of the totality of evidence, a demonstration of similarity between a potential bevacizumab biosimilar and originator bevacizumab in terms of sensitive structural analyses and functional assays will be essential in providing confidence that the biosimilar will behave similarly to the originator, particularly in indications approved by extrapolation.

Following analytical and nonclinical comparative studies, a number of potential bevacizumab biosimilars have progressed to comparative clinical studies with originator bevacizumab (Table 2) [61-67]. As described earlier, regulators require sponsors to conduct a comparative assessment of clinical PK and, where relevant, pharmacodynamics $[45,50-52]$. Such studies should be conducted in the population that is most informative for evaluating potential differences between a biosimilar and the originator product [68]. Studies in healthy volunteers are preferred by some regulatory authorities, given that PK is likely to be less subject to variability in this population than in patients, who may have comorbidities or be receiving concomitant medications [52, 68]. Although crossover studies are favored, the regulatory authorities recognize that parallel-group studies may be necessary given the long half-life and potential for immunogenicity with monoclonal antibody therapies [52, 68]. It is not a regulatory requirement to test a potential biosimilar at all dosages, and the most sensitive dose should be selected for detecting potential PK differences between the biosimilar and originator product [52]; in general, this may be the lowest therapeutic dose [69]. Accordingly, in most of the development programs for potential bevacizumab biosimilars, comparative PK trials were conducted in healthy volunteers and employed a parallel-group, single-dose design using a low dose of bevacizumab (Table 2).

As there are no validated pharmacodynamic markers to assess the efficacy of bevacizumab, biosimilar manufacturers have been required to carry out confirmatory clinical efficacy studies. Such studies of potential biosimilars usually employ an equivalence design, where the aim is to confirm that the biosimilar is neither inferior nor superior to the originator product [70]. Given that the guiding principle is to establish biosimilarity between the biosimilar and originator product, regulatory authorities prefer the use of a patient population and clinical endpoint that will most sensitively detect any product-related differences and minimize the influence of disease- or patient-related factors [45, 52]. Selection of the appropriate study population and endpoint usually follows interactions with regulatory authorities and takes into account historical trials involving the originator, clinical input, and practical issues [70]. With such considerations in mind, most manufacturers of potential bevacizumab biosimilars have designed their comparative clinical efficacy and safety studies in patients with previously untreated advanced NSCLC, using objective/overall response rate (ORR) as the primary endpoint. In these studies, patients with NSCLC will be treated with bevacizumab in combination with paclitaxel and carboplatin, a regimen with a wellcharacterized safety and efficacy profile. In all instances, the dose of bevacizumab or biosimilar used is $15 \mathrm{mg} / \mathrm{kg}$ every 3 weeks, which is the recommended dose of originator bevacizumab in this setting [8]. Survival-based endpoints, while preferred for assessing novel biologics, may be influenced by factors other than treatment-related differences and hence are less suitable for establishing biosimilarity [52]; however, several comparative clinical trials will report survival outcomes as secondary endpoints.

Results are available from comparative clinical trials assessing the efficacy and safety of potential biosimilars ABP 215 and BCD-021 [62, 65]. Taking the trial for ABP 215 as an example, 642 patients with non-squamous NSCLC initiating first-line chemotherapy with paclitaxel and carboplatin were randomized to receive either the potential biosimilar or originator bevacizumab at a dose of $15 \mathrm{mg} /$ $\mathrm{kg}$ every 3 weeks for 6 cycles [62]. ORR in the intention-totreat population was $39.0 \%$ in the ABP 215 group and $41.7 \%$ in the originator bevacizumab group. The risk ratio for ORR was 0.93 , with a $90 \%$ confidence interval of $0.80-1.09$, which fell within the pre-specified margin for similarity $(0.67-1.5)$. Similar safety and immunogenicity were also observed between the study arms [62]. Moreover, secondary efficacy results from this trial indicated similar PFS between the two treatments [63].

In short, there are clear similarities between the clinical development programs for most of the potential bevacizumab biosimilars in terms of study populations, dose selection, endpoints, and sample sizes, which is likely the result of consultation between prospective applicants and regulatory agencies. As further data become available, it will be interesting to observe whether any differentiating factors become apparent among the various biosimilars. 
Table 2 Clinical studies of potential biosimilars to bevacizumab

\begin{tabular}{|c|c|c|c|c|c|c|c|}
\hline Biosimilar & Manufacturer & Design & Population (N) & $\begin{array}{l}\text { Dose of } \\
\text { bevacizumab }\end{array}$ & $\begin{array}{l}\text { Primary } \\
\text { endpoints (time } \\
\text { frame) }\end{array}$ & Current status & $\begin{array}{l}\text { Reference and/or } \\
\text { NCT number* }\end{array}$ \\
\hline \multirow[t]{2}{*}{ ABP 215} & \multirow[t]{2}{*}{ Amgen } & $\begin{array}{l}\text { Randomized, 3-arm, } \\
\text { single-dose study to } \\
\text { assess PK of ABP 215, } \\
\text { BEV-EU, and BEV-US }\end{array}$ & $\begin{array}{l}\text { Healthy adult males } \\
\text { (NR) }\end{array}$ & NR & $\begin{array}{l}\mathrm{AUC}_{0-\text { inf }} ; \mathrm{C}_{\max } \\
\text { (NR) }\end{array}$ & $\begin{array}{l}\text { Completed. Similar } \\
\text { PK profiles }\end{array}$ & Markus et al. [61] \\
\hline & & $\begin{array}{l}\text { Randomized, double-blind } \\
\text { study to compare safety } \\
\text { and efficacy of ABP } 215 \\
\text { and BEV }\end{array}$ & $\begin{array}{l}\text { Advanced } \\
\text { non-squamous } \\
\text { NSCLC (642) }\end{array}$ & $\begin{array}{c}15 \mathrm{mg} / \mathrm{kg} \\
\mathrm{Q} 3 \mathrm{~W}\end{array}$ & $\begin{array}{l}\text { ORR } \\
\text { (19 weeks) }\end{array}$ & $\begin{array}{l}\text { Completed. Similar } \\
\text { efficacy, safety, } \\
\text { and } \\
\text { immunogenicity } \\
\text { profiles }\end{array}$ & $\begin{array}{l}\text { Thatcher et al. [62, } \\
63] \\
\text { NCT01966003 }\end{array}$ \\
\hline \multirow[t]{2}{*}{ BCD-021 } & \multirow[t]{2}{*}{ Biocad } & $\begin{array}{l}\text { PK sub-study of } \\
\text { randomized, } \\
\text { double-blind study }\end{array}$ & $\begin{array}{l}\text { Advanced } \\
\text { non-squamous } \\
\text { NSCLC (28) }\end{array}$ & $15 \mathrm{mg} / \mathrm{kg}$ & $\mathrm{AUC}_{\mathrm{tau}}(504 \mathrm{~h})$ & $\begin{array}{l}\text { Completed. Similar } \\
\text { PK and safety } \\
\text { profiles }\end{array}$ & $\begin{array}{l}\text { Orlov et al. [64] } \\
\quad \text { NCT01763645 }\end{array}$ \\
\hline & & $\begin{array}{l}\text { Randomized, double-blind } \\
\text { study to compare safety } \\
\text { and efficacy of } \\
\text { BCD-021 and BEV }\end{array}$ & $\begin{array}{l}\text { Advanced } \\
\text { non-squamous } \\
\text { NSCLC (138) }\end{array}$ & $\begin{array}{c}15 \mathrm{mg} / \mathrm{kg} \\
\text { Q3W }\end{array}$ & ORR (127 days) & $\begin{array}{l}\text { Completed. Similar } \\
\text { efficacy, safety, } \\
\text { and } \\
\text { immunogenicity } \\
\text { profiles }\end{array}$ & $\begin{array}{l}\text { Filon et al. [65] } \\
\text { NCT01763645 }\end{array}$ \\
\hline BEVZ92 & mAbxience & $\begin{array}{l}\text { Randomized, open-label } \\
\text { study to compare PK and } \\
\text { safety of BEVZ92 and } \\
\text { BEV }\end{array}$ & $\operatorname{mCRC}(142)$ & $\begin{array}{r}5 \mathrm{mg} / \mathrm{kg} \\
\mathrm{Q} 2 \mathrm{~W}\end{array}$ & $\begin{array}{l}\text { PK profile } \\
\quad(15 \text { weeks })\end{array}$ & $\begin{array}{l}\text { Ongoing (primary } \\
\text { completion date } \\
\text { Oct 2015) }\end{array}$ & NCT02069704 \\
\hline \multirow[t]{3}{*}{ BI 695502} & \multirow[t]{3}{*}{$\begin{array}{l}\text { Boehringer } \\
\text { Ingelheim }\end{array}$} & $\begin{array}{l}\text { Randomized, single-blind, } \\
\text { single-dose, 3-arm study } \\
\text { to compare PK and safety } \\
\text { of BI 695502, BEV-EU, } \\
\text { and BEV-US }\end{array}$ & $\begin{array}{l}\text { Healthy male } \\
\quad \text { volunteers (91) }\end{array}$ & $1 \mathrm{mg} / \mathrm{kg}$ & $\begin{array}{l}\mathrm{AUC}_{0-\text { inf }} \\
\quad \text { (99 days) }\end{array}$ & $\begin{array}{l}\text { Completed. Similar } \\
\text { PK and safety } \\
\text { profiles }\end{array}$ & $\begin{array}{l}\text { Hettema et al. [66] } \\
\text { NCT01608087 }\end{array}$ \\
\hline & & $\begin{array}{l}\text { Randomized, double-blind } \\
\text { study to compare effica- } \\
\text { cy and safety of BI } \\
695502 \text { and BEV }\end{array}$ & $\begin{array}{l}\text { Advanced } \\
\text { non-squamous } \\
\text { NSCLC (est. } \\
660 \text { ) }\end{array}$ & NR & $\begin{array}{l}\text { ORR } \\
\quad(18 \text { weeks })\end{array}$ & $\begin{array}{l}\text { Recruiting (est. } \\
\text { primary } \\
\text { completion date } \\
\text { Aug 2017) }\end{array}$ & NCT02272413 \\
\hline & & $\begin{array}{l}\text { Single-arm, open-label } \\
\text { study to evaluate safety } \\
\text { and efficacy }\end{array}$ & mCRC (est. 120) & NR & $\begin{array}{l}\text { Selected AEs } \\
\quad(16.5 \text { months })\end{array}$ & $\begin{array}{l}\text { Recruiting (est. } \\
\text { primary } \\
\text { completion date } \\
\text { Nov 2018) }\end{array}$ & NCT02776683 \\
\hline \multirow[t]{2}{*}{ CBT124 } & \multirow[t]{2}{*}{ Cipla BioTec } & $\begin{array}{l}\text { Randomized, double-blind, } \\
\text { single-dose, 3-arm study } \\
\text { to compare PK and safe- } \\
\text { ty of CBT124, BEV-EU, } \\
\text { and BEV-US }\end{array}$ & $\begin{array}{l}\text { Healthy male } \\
\text { volunteers (est. } \\
150)\end{array}$ & $1 \mathrm{mg} / \mathrm{kg}$ & $\begin{array}{l}\mathrm{AUC}_{0 \text {-inf }} \\
\quad \text { (95 days) }\end{array}$ & $\begin{array}{l}\text { Recruiting (est. } \\
\text { primary } \\
\text { completion date }^{\mathrm{a}} \\
\text { Oct 2016) }\end{array}$ & NCT02747823 \\
\hline & & $\begin{array}{l}\text { Randomized, double-blind } \\
\text { study to compare } \\
\text { efficacy, safety, and } \\
\text { immunogenicity of } \\
\text { CBT124 and BEV-EU }\end{array}$ & $\begin{array}{l}\text { Advanced } \\
\text { non-squamous } \\
\text { NSCLC (est. } \\
\text { 200) }\end{array}$ & $\begin{array}{c}15 \mathrm{mg} / \mathrm{kg} \\
\text { Q3W }\end{array}$ & $\begin{array}{l}\text { ORR } \\
\text { (19 weeks) }\end{array}$ & $\begin{array}{l}\text { Planned (est. } \\
\text { primary } \\
\text { completion date } \\
\text { Dec 2017) }\end{array}$ & NCT02879097 \\
\hline FKB238 & $\begin{array}{l}\text { Centus } \\
\text { Biotherapeu- } \\
\text { tics }\end{array}$ & $\begin{array}{l}\text { Randomized, double-blind } \\
\text { study to compare safety } \\
\text { and efficacy of FKB238 } \\
\text { and BEV }\end{array}$ & $\begin{array}{l}\text { Advanced/recurrent } \\
\text { non-squamous } \\
\text { NSCLC (est. } \\
730 \text { ) }\end{array}$ & $\begin{array}{c}15 \mathrm{mg} / \mathrm{kg} \\
\mathrm{Q} 3 \mathrm{~W}\end{array}$ & $\begin{array}{l}\text { ORR } \\
\quad(12 \text { months })\end{array}$ & $\begin{array}{l}\text { Recruiting (est. } \\
\text { completion date } \\
\text { Jun 2019) }\end{array}$ & NCT02810457 \\
\hline \multirow[t]{2}{*}{ PF-06439535 } & \multirow[t]{2}{*}{ Pfizer } & $\begin{array}{l}\text { Randomized, double-blind, } \\
\text { single-dose, 3-arm study } \\
\text { to compare PK of } \\
\text { PF-06439535, BEV-EU, } \\
\text { and BEV-US }\end{array}$ & $\begin{array}{l}\text { Healthy male } \\
\quad \text { volunteers }(102)\end{array}$ & $5 \mathrm{mg} / \mathrm{kg}$ & $\begin{array}{c}\mathrm{C}_{\text {max }} ; \mathrm{AUC}_{\mathrm{tau}} ; \\
\mathrm{AUC}_{0-\mathrm{inf}} \\
(71 \text { days })\end{array}$ & $\begin{array}{l}\text { Completed. } \\
\text { Similar PK and } \\
\text { safety profiles }\end{array}$ & $\begin{array}{l}\text { Knight et al. [67] } \\
\text { NCT02031991 }\end{array}$ \\
\hline & & $\begin{array}{l}\text { Randomized, double-blind } \\
\text { study to compare safety } \\
\text { and efficacy of } \\
\text { PF-06439535 and } \\
\text { BEV-EU }\end{array}$ & $\begin{array}{l}\text { Advanced } \\
\text { non-squamous } \\
\text { NSCLC (est. } \\
710 \text { ) }\end{array}$ & $\begin{array}{c}15 \mathrm{mg} / \mathrm{kg} \\
\text { Q3W }\end{array}$ & $\begin{array}{l}\text { ORR } \\
\quad(19 \text { weeks })\end{array}$ & $\begin{array}{l}\text { Recruiting (est. } \\
\text { primary } \\
\text { completion date }^{\mathrm{a}} \\
\text { May 2017) }\end{array}$ & NCT02364999 \\
\hline SB8 & $\begin{array}{l}\text { Samsung } \\
\text { Bioepis }\end{array}$ & $\begin{array}{l}\text { Randomized, double-blind, } \\
\text { single-dose, 3-arm study } \\
\text { to compare PK, safety, } \\
\text { and immunogenicity of }\end{array}$ & $\begin{array}{l}\text { Healthy male } \\
\quad \text { volunteers (119) }\end{array}$ & $3 \mathrm{mg} / \mathrm{kg}$ & $\begin{array}{c}\mathrm{C}_{\mathrm{max}} ; \mathrm{AUC}_{\mathrm{tau}} \\
\mathrm{AUC}_{0-\text { inf }} \\
(85 \text { days })\end{array}$ & Completed & NCT02453672 \\
\hline
\end{tabular}


Table 2 (continued)

\begin{tabular}{|c|c|c|c|c|c|c|c|}
\hline \multirow[t]{3}{*}{ Biosimilar } & Manufacturer & Design & Population (N) & $\begin{array}{l}\text { Dose of } \\
\text { bevacizumab }\end{array}$ & $\begin{array}{l}\text { Primary } \\
\text { endpoints (time } \\
\text { frame) }\end{array}$ & Current status & $\begin{array}{l}\text { Reference and/or } \\
\text { NCT number* }\end{array}$ \\
\hline & & $\begin{array}{l}\text { SB8, BEV-EU, and } \\
\text { BEV-US }\end{array}$ & & & & & \\
\hline & & $\begin{array}{l}\text { Randomized, double-blind } \\
\text { study to compare safety, } \\
\text { efficacy, PK, and } \\
\text { immunogenicity of SB8 } \\
\text { and BEV-EU }\end{array}$ & $\begin{array}{l}\text { Advanced } \\
\text { non-squamous } \\
\text { NSCLC (est. } \\
678)\end{array}$ & $\begin{array}{c}15 \mathrm{mg} / \mathrm{kg} \\
\mathrm{Q} 3 \mathrm{~W}\end{array}$ & $\begin{array}{l}\text { ORR } \\
\quad(24 \text { weeks })\end{array}$ & $\begin{array}{l}\text { Recruiting (est. } \\
\text { primary } \\
\text { completion date } \\
\text { Jun 2018) }\end{array}$ & NCT02754882 \\
\hline
\end{tabular}

Table last updated in May 2017

$A E s$ adverse events, $A U C_{0-\text { inf }}$ area under the curve from time zero to extrapolated infinite time, $A U C_{\text {tau }}$ area under the curve from time zero to last quantifiable concentration, $B E V$ bevacizumab, $B E V$-EU bevacizumab sourced from the European Union, $B E V-U S$ bevacizumab sourced from the United States, $C_{\max }$ maximum serum concentration; est., estimated, $m C R C$ metastatic colorectal cancer, NCT National Clinical Trial, NR not reported, NSCLC non-small-cell lung cancer, $O R R$ objective/overall response rate, $P K$ pharmacokinetics, $Q 2 W$ every 2 weeks, $Q 3 W$ every 3 weeks

*Biosimilars included are those with trials registered at ClinicalTrials.gov; other potential biosimilars may also be in development

${ }^{a}$ Primary completion date refers to date of final data collection for primary outcome measure

\subsection{Extrapolation}

Where the totality of evidence from the comparison exercise for a potential biosimilar demonstrates a high degree of similarity to the originator, approval of the biosimilar for indications not studied during the clinical step may be possible. Extrapolation can be relatively straightforward for a biologic with a well-characterized mechanism of action that is the same across indications [53]. However, it may be more challenging in cases where the mechanism of action of the active substance is complex or not well understood and involves multiple receptors or binding sites, which may differ in their significance between different disease states [53, 69]. Indeed, when biosimilar infliximab CT-P13 was authorized for use in extrapolated indications, the extent to which the Fc domain of the antibody contributes to the mechanism of action in different disease states was a point of debate within the scientific community [71].

Two potential bevacizumab biosimilars (BEVZ92 and BI 695502) are being studied in patients with mCRC (Table 2). The study for BI 695502 (NCT02776683) is an open-label, single-arm study that will evaluate the potential biosimilar in combination with FOLFOX as first-line therapy. The primary endpoint is safety, and the dose used in the study is not currently known; the study results will presumably be used to complement data from a larger comparative clinical trial of BI 695502 and originator bevacizumab in NSCLC. The study for BEVZ92 (NCT02069704) is an open-label, randomized comparison of the biosimilar and the originator, both in combination with either FOLFOX or FOLFIRI (folinic acid, fluorouracil, irinotecan), in the first-line setting. The dose of bevacizumab or BEVZ92 used in the study is $5 \mathrm{mg} / \mathrm{kg}$ every 2 weeks (in the US, the recommended doses of originator bevacizumab when used in combination with intravenous fluorouracil-based chemotherapy are 5 or $10 \mathrm{mg} / \mathrm{kg}$ every 2 weeks [8]). The primary endpoint is PK, and it is not known if this potential biosimilar is being studied in other clinical trials.

As a result, in most instances, authorization of bevacizumab biosimilars for $\mathrm{mCRC}$ will require extrapolation. Importantly, as no bevacizumab biosimilars have yet been assessed by a regulator in a region with a stringent biosimilar approval pathway, the scientific evidence that sponsors may use to support extrapolation is not yet known. Relevant factors that may need to be addressed include: the mechanism of action of bevacizumab in different disease states; PK and tissue distribution in different indications; and any differences in the immunogenicity or toxicity profile between disease states [45]. Importantly, differences between disease states in the above parameters do not necessarily preclude extrapolation if there are convincing supportive scientific rationales [45]. Where there is residual uncertainty about whether the biosimilar will behave similarly to the originator product in extrapolated indications, additional studies may be performed, but they need not be clinical in nature. Indeed, from a scientific perspective, it is reasoned that the comparative analytical analyses that underlie a determination of biosimilarity (e.g. functional assays) are able to detect product-related differences between a biosimilar and originator more sensitively than comparative clinical trials $[53,72]$.

Should a potential bevacizumab biosimilar demonstrate a high degree of similarity to originator bevacizumab across all stages of the comparison exercise, including in a clinical study or studies in an indication sensitive to detect potential differences, observations from the literature concerning originator bevacizumab that may be relevant to decisions regarding extrapolation include: 
- A population PK model for bevacizumab that included an assessment of indication as a covariate did not identify a significant effect of tumor type on PK, whereas estimates of clearance and central volume of distribution were found to be affected by body weight and gender, for example [73].

- Immunogenicity to originator bevacizumab is low; the US label states that $0.63 \%$ of patients $(14 / 2233)$ treated for adjuvant colon carcinoma (not a licensed indication) exhibited treatment-emergent antidrug antibodies [8].

As should be clear from the discussion above, the regulatory decision regarding whether indications are authorized by extrapolation is not dependent solely on clinical data for a potential biosimilar [74]. Extrapolation is considered within the context of the totality of the evidence from all stages of the comparison exercise.

Based on the access barriers discussed above, it is not surprising that, in a recent study, the majority of surveyed oncologists were reported as likely to prescribe a bevacizumab biosimilar for patients with $\mathrm{mCRC}$, if one was available [12]. Indeed, mCRC was ranked by respondents as the tumor type in which a bevacizumab biosimilar could have the greatest impact on patient outcomes. Cost and efficacy were reported as the main factors that would drive prescribing across tumor types. Based on the views of those oncologists who reported being unlikely to prescribe a bevacizumab biosimilar, acceptance may be enhanced by the availability of efficacy and safety data in specific tumor types [12]. Thus, although indication extrapolation avoids the need for unnecessary clinical trials in all patient populations, it may be a challenging concept for some clinicians.

\section{Conclusions and Outlook}

In summary, several candidate biosimilars to bevacizumab are in advanced stages of development, with further regulatory submissions expected following the completion of comparative clinical trials in the next several years. Based on experience with biosimilars to date, the introduction of bevacizumab biosimilars will be accompanied by the expectation of cost savings and expanded access for patients [12]. Given the significant benefits associated with the use of bevacizumab in $\mathrm{mCRC}$, wider use is a tantalizing prospect. Along with the potential for increased use overall, treatment patterns may evolve such that more patients with $\mathrm{mCRC}$ can access prolonged treatment with bevacizumab in maintenance regimens or in treatment beyond progression, for example. Additionally, enhanced access may enable use of bevacizumab in evidence-based regimens that are less commonly used, such as first-line bevacizumab plus capecitabine in elderly patients for whom oxaliplatin- or irinotecan-based regimens may be unsuitable [16].

In most cases, authorization of bevacizumab biosimilars for $\mathrm{mCRC}$ indications will be via extrapolation and, as such, it will be interesting to observe how accepting oncologists will be. Based on the validation of the biosimilar concept through the significant clinical experience accrued with biosimilars to date, it is hoped that the global medical community will embrace these potential new treatment options as we strive to improve treatment access and clinical outcomes for patients with mCRC.

\section{Compliance with Ethical Standards}

Funding Medical writing support was provided by Paul Shepherd of Engage Scientific Solutions and was funded by Pfizer.

Conflict of Interest Lee Rosen has received research funding from Lilly, Pfizer, and Regeneron, and an honorarium from Pfizer for participation in an advisory board. Ira Jacobs is an employee of and holds stock or stock options in Pfizer Inc. Ronald Burkes has received honoraria from and acted as a consultant or advisor to Eli Lilly, Roche, Amgen, Boehringer Ingelheim, AstraZeneca, Merck, and the EMD-Serono/ Pfizer alliance.

Open Access This article is distributed under the terms of the Creative Commons Attribution-NonCommercial 4.0 International License (http:// creativecommons.org/licenses/by-nc/4.0/), which permits any noncommercial use, distribution, and reproduction in any medium, provided you give appropriate credit to the original author(s) and the source, provide a link to the Creative Commons license, and indicate if changes were made.

\section{References}

1. International Agency for Research on Cancer, World Health Organization. GLOBOCAN 2012: estimated cancer incidence, mortality and prevalence worldwide in 2012. World fact sheet. 2012 (last update 2012). http://globocan.iarc.fr/Pages/fact sheets population.aspx Accessed 8 Sept 2016

2. Brenner H, Kloor M, Pox CP. Colorectal cancer. Lancet. 2014;383: 1490-502. doi:10.1016/S0140-6736(13)61649-9.

3. National Cancer Institute. SEER cancer statistics factsheets: colon and rectum cancer. 2016 (last update 2016). http://seer.cancer.gov/ statfacts/html/colorect.html Accessed 23 Aug 2016.

4. Van Cutsem E, Cervantes A, Nordlinger B, Arnold D. Metastatic colorectal cancer: ESMO clinical practice guidelines for diagnosis, treatment and follow-up. Ann Oncol. 2014;25:iii1-9. doi:10.1093/ annonc/mdu260.

5. Van Cutsem E, Cervantes A, Adam R, Sobrero A, Van Krieken JH, Aderka D, et al. ESMO consensus guidelines for the management of patients with metastatic colorectal cancer. Ann Oncol. 2016;27: 1386-422. doi:10.1093/annonc/mdw235.

6. Kasi PM, Hubbard JM, Grothey A. Selection of biologics for patients with metastatic colorectal cancer: the role of predictive markers. Expert Rev Gastroenterol Hepatol. 2015;9:273-6. doi: 10.1586/17474124.2015.1001743.

7. Roche Registration Limited. Avastin (bevacizumab) summary of product characteristics. 2009 (last update 10/19/2016). http:// 
www.ema.europa.eu/docs/en_GB/document_library/EPAR__Product_Information/human/000582/WC500029271.pdf Accessed 21 Oct 2016.

8. Genentech Inc. Avastin ${ }^{\circledR}$ (bevacizumab) prescribing information. 2004 (last update 2016). https://www.accessdata.fda.gov/ drugsatfda_docs/label/2016/125085s317lbl.pdf Accessed 16 May 2017.

9. Cherny N, Sullivan R, Torode J, Saar M, Eniu A. ESMO European consortium study on the availability, out-of-pocket costs and accessibility of antineoplastic medicines in Europe. Ann Oncol. 2016;27: 1423-43. doi:10.1093/annonc/mdw213.

10. Baer WH, Maini A, Jacobs I. Barriers to the access and use of rituximab in patients with non-Hodgkin's lymphoma and chronic lymphocytic leukemia: a physician survey. Pharmaceuticals (Basel). 2014;7:530-44. doi:10.3390/ph7050530.

11. Lammers P, Criscitiello C, Curigliano G, Jacobs I. Barriers to the use of trastuzumab for HER2+ breast cancer and the potential impact of biosimilars: a physician survey in the United States and emerging markets. Pharmaceuticals (Basel). 2014;7:943-53. doi: $10.3390 / \mathrm{ph} 7090943$.

12. Monk BJ, Lammers PE, Cartwright T, Jacobs I. Barriers to the access of bevacizumab in patients with solid tumors and the potential impact of biosimilars: a physician survey. Pharmaceuticals (Basel). 2017. doi:10.3390/ph10010019.

13. Hurwitz H, Fehrenbacher L, Novotny W, Cartwright T, Hainsworth $\mathrm{J}$, Heim W, et al. Bevacizumab plus irinotecan, fluorouracil, and leucovorin for metastatic colorectal cancer. N Engl J Med. 2004;350:2335-42. doi:10.1056/NEJMoa032691.

14. Giantonio BJ, Catalano PJ, Meropol NJ, O'Dwyer PJ, Mitchell EP, Alberts SR, et al. Bevacizumab in combination with oxaliplatin, fluorouracil, and leucovorin (FOLFOX4) for previously treated metastatic colorectal cancer: results from the Eastern Cooperative Oncology Group Study E3200. J Clin Oncol. 2007;25:1539-44. doi:10.1200/JCO.2006.09.6305.

15. Bennouna J, Sastre J, Arnold D, Osterlund P, Greil R, Van Cutsem $\mathrm{E}$, et al. Continuation of bevacizumab after first progression in metastatic colorectal cancer (ML18147): a randomised phase 3 trial. Lancet Oncol. 2013;14:29-37. doi:10.1016/S1470-2045(12) 70477-1.

16. Cunningham D, Lang I, Marcuello E, Lorusso V, Ocvirk J, Shin $\mathrm{DB}$, et al. Bevacizumab plus capecitabine versus capecitabine alone in elderly patients with previously untreated metastatic colorectal cancer (AVEX): an open-label, randomised phase 3 trial. Lancet Oncol. 2013;14:1077-85. doi:10.1016/S1470-2045(13)70154-2.

17. Guan ZZ, Xu JM, Luo RC, Feng FY, Wang LW, Shen L, et al. Efficacy and safety of bevacizumab plus chemotherapy in Chinese patients with metastatic colorectal cancer: a randomized phase III ARTIST trial. Chin J Cancer Res. 2011;30:682-9. doi: 10.5732/cjc.011.10188.

18. Kabbinavar F, Hurwitz HI, Fehrenbacher L, Meropol NJ, Novotny WF, Lieberman G, et al. Phase II, randomized trial comparing bevacizumab plus fluorouracil (FU)/leucovorin (LV) with FU/LV alone in patients with metastatic colorectal cancer. J Clin Oncol. 2003;21:60-5. doi:10.1200/JCO.2003.10.066.

19. Kabbinavar FF, Schulz J, McCleod M, Patel T, Hamm JT, Hecht JR, et al. Addition of bevacizumab to bolus fluorouracil and leucovorin in first-line metastatic colorectal cancer: results of a randomized phase II trial. J Clin Oncol. 2005;23:3697-705. doi:10.1200/JCO. 2005.05.112.

20. Passardi A, Nanni O, Tassinari D, Turci D, Cavanna L, Fontana A, et al. Effectiveness of bevacizumab added to standard chemotherapy in metastatic colorectal cancer: final results for first-line treatment from the ITACa randomized clinical trial. Ann Oncol. 2015;26:1201-7. doi:10.1093/annonc/mdv130

21. Saltz LB, Clarke S, Diaz-Rubio E, Scheithauer W, Figer A, Wong $\mathrm{R}$, et al. Bevacizumab in combination with oxaliplatin-based chemotherapy as first-line therapy in metastatic colorectal cancer: a randomized phase III study. J Clin Oncol. 2008;26:2013-9. doi: 10.1200/JCO.2007.14.9930.

22. Stathopoulos GP, Batziou C, Trafalis D, Koutantos J, Batzios S, Stathopoulos J, et al. Treatment of colorectal cancer with and without bevacizumab: a phase III study. Oncology. 2010;78:376-81. doi:10.1159/000320520.

23. Tebbutt NC, Wilson K, Gebski VJ, Cummins MM, Zannino D, van Hazel GA, et al. Capecitabine, bevacizumab, and mitomycin in first-line treatment of metastatic colorectal cancer: results of the Australasian Gastrointestinal Trials Group Randomized Phase III MAX Study. J Clin Oncol. 2010;28:3191-8. doi:10.1200/JCO. 2009.27.7723.

24. Botrel TE, Clark LG, Paladini L, Clark OA. Efficacy and safety of bevacizumab plus chemotherapy compared to chemotherapy alone in previously untreated advanced or metastatic colorectal cancer: a systematic review and meta-analysis. BMC Cancer. 2016;16:677. doi:10.1186/s12885-016-2734-y.

25. Qu CY, Zheng Y, Zhou M, Zhang Y, Shen F, Cao J, et al. Value of bevacizumab in treatment of colorectal cancer: a meta-analysis. World J Gastroenterol. 2015;21:5072-80. doi:10.3748/wjg.v21. i16.5072.

26. Masi G, Salvatore L, Boni L, Loupakis F, Cremolini C, Fornaro L, et al. Continuation or reintroduction of bevacizumab beyond progression to first-line therapy in metastatic colorectal cancer: final results of the randomized BEBYP trial. Ann Oncol. 2015;26:72430. doi:10.1093/annonc/mdv012.

27. Strickler JH, Hurwitz HI. Bevacizumab-based therapies in the firstline treatment of metastatic colorectal cancer. Oncologist. 2012;17: 513-24. doi:10.1634/theoncologist.2012-0003.

28. Sclafani F, Cunningham D. Bevacizumab in elderly patients with metastatic colorectal cancer. J Geriatr Oncol. 2014;5:78-88. doi:10. 1016/j.jgo.2013.08.006.

29. Ciardiello F. Maintenance therapy for metastatic colorectal cancer. Lancet Oncol. 2015;16:1444-5. doi:10.1016/S1470-2045(15) 00308-3.

30. Renouf DJ, Lim HJ, Speers C, Villa D, Gill S, Blanke CD, et al. Survival for metastatic colorectal cancer in the bevacizumab era: a population-based analysis. Clin Colorectal Cancer. 2011;10:97101. doi:10.1016/j.clcc.2011.03.004.

31. Tomita Y, Karapetis CS, Ullah S, Townsend AR, Roder D, Beeke C, et al. Survival improvements associated with access to biological agents: results from the south Australian (SA) metastatic colorectal cancer (mCRC) registry. Acta Oncol. 2016;55:480-5. doi:10.3109/ 0284186X.2015.1117135.

32. Chan KK, Wong B, Siu LL, Straus SE, Chang J, Berry SR. Less than ideal: how oncologists practice with limited drug access. J Oncol Pract. 2012;8:190-5. doi:10.1200/JOP.2011.000337.

33. Li E, Schleif R, Edelen B. Hospital management of outpatient oncology treatment decisions: a survey to identify strategies and concerns. J Oncol Pract. 2013;9:e248-54. doi:10.1200/JOP.2012. 000814.

34. Nadler E, Eckert B, Neumann PJ. Do oncologists believe new cancer drugs offer good value? Oncologist. 2006;11:90-5. doi:10.1634/theoncologist.11-2-90.

35. Skopec L. ACS CAN examination of cancer drug coverage and transparency in the health insurance marketplaces. 2015 (last update 11/18/2015). https://www.acscan.org/sites/default/files/ACS\% 20CAN\%20Drug\%20Formulary\%20Paper\%202015.pdf Accessed 1 Feb 2017

36. Chamberlain C, Collin SM, Stephens P, Donovan J, Bahl A, Hollingworth W. Does the cancer drugs fund lead to faster uptake of cost-effective drugs? A time-trend analysis comparing England and Wales. Br J Cancer. 2014;111:1693-702. doi:10.1038/bjc. 2014.86. 
37. NHS England. National cancer drugs fund list. 2015 (last update 11/ 4/2015). http://webarchive.nationalarchives.gov.uk/ 20151223153822/https://www.england.nhs.uk/wp-content/ uploads/2015/11/ncdf-list-nov-15.pdf Accessed 20 Jan 2017.

38. Whyte S, Pandor A, Stevenson M. Bevacizumab for metastatic colorectal cancer: a NICE single technology appraisal. Pharmacoeconomics. 2012;30:1119-32. doi:10.2165/11597210000000000-00000.

39. National Institute for Health and Care Excellence. Bevacizumab in combination with oxaliplatin and either fluorouracil plus folinic acid or capecitabine for the treatment of metastatic colorectal cancer. 2010 (last update 12/5/2010). https://www.nice.org.uk/ guidance/ta212 Accessed 2 May 2017.

40. Li E, Subramanian J, Anderson S, Thomas D, McKinley J, Jacobs IA. Development of biosimilars in an era of oncologic drug shortages. Drug Des Devel Ther. 2015;9:3247-55. doi: 10.2147/DDDT.S75219.

41. Mackey TK, Cuomo R, Guerra C, Liang BA. After counterfeit Avastin ${ }^{\circledR}$-what have we learned and what can be done? Nat Rev Clin Oncol. 2015;12:302-8. doi:10.1038/nrclinonc.2015.35.

42. Bikov KA, Mullins CD, Hung A, Seal B, Onukwugha E, Hanna N. Patterns of biologics use across treatment lines in elderly (age $>65$ ) Medicare patients with metastatic colon cancer. Oncologist. 2016;21:676-83. doi:10.1634/theoncologist.2015-0199.

43. Blackstone EA, Fuhr Jr JP, Pociask S. The health and economic effects of counterfeit drugs. Am Health Drug Benefits. 2014;7:21624.

44. Cuomo RE, Mackey TK, Stigler P. The economics of counterfeit Avastin: a geospatial and statistical analysis of demographic correlates to FDA warning letters. Pharmacoepidemiol Drug Saf. 2015;24:748-56. doi:10.1002/pds.3796.

45. US Food and Drug Administration. Scientific considerations in demonstrating biosimilarity to a reference product: guidance for industry. 2015 (last update 4/2015). http://www.fda.gov/ downloads/DrugsGuidanceComplianceRegulatoryInformation/ Guidances/UCM291128.pdf Accessed 10 June 2016.

46. IMS Health. The impact of biosimilar competition. 2016 (last update 6/2016). http://ec.europa.eu/DocsRoom/documents/17325/ attachments/1/translations/en/renditions/native Accessed 19 Sept 2016.

47. Pettengell R, Bias P, Mueller U, Lang N. Clinical safety of tbofilgrastim, a short-acting human granulocyte colony-stimulating factor. Support Care Cancer. 2016;24:2677-84. doi:10.1007/ s00520-015-3057-2.

48. Gascón P, Tesch H, Verpoort K, Rosati MS, Salesi N, Agrawal S, et al. Clinical experience with Zarzio(R) in Europe: what have we learned? Support Care Cancer. 2013;21:2925-32. doi:10.1007/ s00520-013-1911-7.

49. Celltrion Healthcare Hungary Kft. Truxima. Summary of product characteristics. 2017 (last update 3/8/2017). http://www.ema. europa.eu/docs/en_GB/document library/EPAR - Product Information/human/004112/WC500222694.pdf Accessed 15 Mar 2017.

50. Health Canada. Guidance document: information and submission requirements for biosimilar biologic drugs. 2016 (last update 11/14/ 2016). http://www.hc-sc.gc.ca/dhp-mps/alt formats/pdf/brgtherap/ applic-demande/guides/seb-pbu/seb-pbu-2016-eng.pdf Accessed 16 Dec 2016.

51. European Medicines Agency. Guideline on similar biological medicinal products. 2014 (last update 4/30/2015). http://www.ema. europa.eu/docs/en GB/document library/Scientific guideline/ 2014/10/WC500176768.pdf Accessed 9 June 2016.

52. European Medicines Agency. Guideline on similar biological medicinal products containing monoclonal antibodies - non-clinical and clinical issues. 2012 (last update 12/1/2012). http://www.ema.
europa.eu/docs/en_GB/document_library/Scientific_guideline/ 2012/06/WC500128686.pdf Accessed 20 July 2016.

53. Weise M, Kurki P, Wolff-Holz E, Bielsky MC, Schneider CK. Biosimilars: the science of extrapolation. Blood. 2014;124:31916. doi:10.1182/blood-2014-06-583617.

54. Rugo HS, Linton KM, Cervi P, Rosenberg JA, Jacobs I. A clinician's guide to biosimilars in oncology. Cancer Treat Rev. 2016;46: 73-9. doi:10.1016/j.ctrv.2016.04.003.

55. Amgen. Amgen and Allergan submit biosimilar Biologics License Application for ABP 215 to U.S. Food and Drug Administration. 2016 (last update 11/15/2016). http://wwwext.amgen.com/media/ news-releases/2016/11/amgen-and-allergan-submit-biosimilarbiologics-license-application-for-abp-215-to-u-s-food-and-drugadministration/ Accessed 19 Jan 2017.

56. Amgen. Amgen and Allergan submit biosimilar Marketing Authorization Application to European Medicines Agency for ABP 215, a biosimilar candidate to bevacizumab. 2016 (last update 12/2/16). http://wwwext.amgen.com/media/news-releases/2016/ 12 /amgen-and-allergan-submit-biosimilar-marketingauthorization-application-to-european-medicines-agency-for-abp215-a-biosimilar-candidate-to-bevacizumab/ Accessed 19 Jan 2017.

57. Wang Y, Fei D, Vanderlaan M, Song A. Biological activity of bevacizumab, a humanized anti-VEGF antibody in vitro. Angiogenesis. 2004;7:335-45. doi:10.1007/s10456-004-8272-2.

58. Muller YA, Chen Y, Christinger HW, Li B, Cunningham BC, Lowman HB, et al. VEGF and the Fab fragment of a humanized neutralizing antibody: crystal structure of the complex at 2.4 a resolution and mutational analysis of the interface. Structure. 1998;6: 1153-67.

59. Born TL, Huynh Q, Mathur A, Velayudhan J, Canon J, Reynhardt $\mathrm{K}$, et al. 489P Functional similarity assessment results comparing bevacizumab to biosimilar candidate ABP 215. Presented at the 39th European Society for Medical Oncology Congress, Madrid, Spain, 26-30 Sep, 2014.

60. Rule K, Peraza M, Shiue M, Finch G, Thibault S, Rosenberg JA, et al. Nonclinical development of PF-06439535, a potential biosimilar to bevacizumab. J Thorac Oncol. 2015;10 suppl 2:S485.

61. Markus R, Born T, Chow V, Zhang N, Huynh Q, Maher G, et al. Functional similarity and human pharmacokinetic $(\mathrm{PK})$ equivalence of ABP 215 and bevacizumab. J Clin Oncol. 2015;33:(Suppl.) [abstract e14659].

62. Thatcher N, Thomas M, Paz-Ares L, Ostoros G, Pan Z, Goldschmidt JH, et al. Randomized, double-blind, phase 3 study evaluating efficacy and safety of ABP 215 compared with bevacizumab in patients with non-squamous NSCLC. J Clin Oncol. 2016;34:(Suppl.) [abstract 9095].

63. Thatcher N, Thomas M, Ostoros G, Pan Z, Goldschmidt JH, Hanes V. Secondary efficacy results from a phase 3 study comparing efficacy and safety of biosimilar candidate ABP 215 with bevacizumab in patients with non-squamous non-small cell lung cancer (NSCLC). Ann Oncol. 2016;27:vi411-5. doi:10.1093/annonc/ mdw382.10.

64. Orlov SV, Burdaeva ON, Nachaeva MP, Kopp MV, Kotiv BN, Sheveleva LP, et al. Pharmacokinetics and safety of BCD-021, bevacizumab biosimilar candidate, compared to Avastin in patients. J Clin Oncol. 2014;32:(Suppl.) [abstract e13500].

65. Filon O, Orlov S, Burdaeva O, Kopp MV, Kotiv B, Alekseev S, et al. Efficacy and safety of BCD-021, bevacizumab biosimilar candidate, compared to Avastin: Results of international multicenter randomized double blind phase III study in patients with advanced non-squamous NSCLC. J Clin Oncol. 2015;33:(Suppl.) [abstract 8057].

66. Hettema W, Wynne C, Schliephake D, Lang B, Altendorfer M, Czeloth N. A randomized, single-blind, phase I trial (INVICTAN ${ }^{\circledR}-1$ ) assessing the pharmacokinetic bioequivalence 
and safety of BI 695502, a bevacizumab biosimilar candidate, in healthy subjects. 2016 (last update 11/2016). http://abstracts.aaps. org/Verify/AAPS2016/PosterSubmissions/08W1230.pdf Accessed 18 Jan 2017.

67. Knight B, Rassam D, Liao S, Ewesuedo R. A phase I pharmacokinetics study comparing PF-06439535 (a potential biosimilar) with bevacizumab in healthy male volunteers. Cancer Chemother Pharmacol. 2016;77:839-46. doi:10.1007/s00280-016-3001-2.

68. US Food and Drug Administration. Clinical pharmacology data to support a demonstration of biosimilarity to a reference product. Guidance for industry. 2016 (last update 12/2016). http://www. f d a . g o v / d o w n 1 o a d s / d r u g s / guidancecomplianceregulatoryinformation/guidances/ucm397017. pdf Accessed 30 Jan 2017.

69. World Health Organization. Guidelines on evaluation of monoclonal antibodies as similar biotherapeutic products (SBPs). 2016 (last update 10/2016). http://www.who.int/biologicals/expert committee/mAb_SBP_GL-ECBS_review adoption-2016.10.2611.7post_ECBS-Clean_Version.pdf?ua=1 Accessed 12 Apr 2017.
70. Isakov L, Jin B, Jacobs IA. Statistical primer on biosimilar clinical development. Am J Ther. 2016;23:e1903-e10. doi:10.1097/MJT. 0000000000000391.

71. Feagan BG, Choquette D, Ghosh S, Gladman DD, Ho V, Meibohm $\mathrm{B}$, et al. The challenge of indication extrapolation for infliximab biosimilars. Biologicals. 2014;42:177-83. doi:10.1016/j. biologicals.2014.05.005.

72. Christl LA, Woodcock J, Kozlowski S. Biosimilars: the US regulatory framework. Annu Rev Med. 2017;68:243-54. doi:10.1146/ annurev-med-051215-031022.

73. Han K, Peyret T, Marchand M, Quartino A, Gosselin NH, Girish S, et al. Population pharmacokinetics of bevacizumab in cancer patients with external validation. Cancer Chemother Pharmacol. 2016;78:341-51. doi:10.1007/s00280-016-3079-6.

74. Declerck P, Danesi R, Petersel D, Jacobs I. The language of biosimilars: clarification, definitions, and regulatory aspects. Drugs. 2017;77:671-7. doi:10.1007/s40265-017-0717-1. 